\title{
Psychomotor development differences between Czech adolescents from orphanages and adolescents from majority society
}

\author{
Jakub Holický*, Jakub Kokštejn, and Martin Musálek \\ Faculty of Physical Education and Sport, Charles University, Prague, Czech Republic
}

Copyright: (c) 2015 J. Holický et al. This is an open access article licensed under the Creative Commons Attribution License (http://creativecommons.org/licenses/by/4.0/).

Background: The results of foreign studies have shown that psychomotor development of adolescents from orphanages falls significantly behind common developmental norms. In the Czech Republic, there is a lack of evidence of this issue despite the fact that some experts emphasize the possible defects of institutional care in the Czech Republic. Objective: The purpose of the study was to compare the level of psychomotor development of 13 year old adolescents from orphanages located in Prague and their counterparts from majority society. Methods: Psychomotor development of adolescents was tested with the complete form of the Bruininks-Oseretsky Test of Motor Proficiency, second edition (BOT-2), which consists of 52 items, divided into 12 dimensions assessing the level of fine motor skills, gross motor skills, coordination and agility. The study sample consisting of 57 adolescents (age $13.47 \pm 0.26$ years) included a sample of 21 adolescents from orphanages and 36 adolescents from majority society living in the Prague region. Results: Compared to their counterparts from majority society, adolescents from orphanages achieved significantly lower scores only in the fine motor precision dimension $\left(\eta^{2}=.13 ; p=.032\right)$. The study showed significant difference between boys from orphanages and boys from majority society in the fine motor precision dimension $\left(\eta^{2}=.13 ; p=.028\right)$, boys from majority society achieved significantly higher scores in this dimension. The results did not find significant difference in any BOT-2 dimensions between girls from majority society and girls from orphanages. Adolescents from orphanages achieved higher scores in the dimensions of strength and agility, running speed and agility and strength. Conclusion: Differences in psychomotor development were not confirmed in the observed dimensions of bilateral coordination and balance between the sample of adolescents from orphanages in Prague and their counterparts from majority society. This may be attributed to the specificity of institutional care in the Czech Republic.

Keywords: Bruininks-Oseretsky Test of Motor Proficiency, fine and gross motor skills, bilateral coordination, gender differences

\section{Introduction}

At present, institutional care of children from orphanages is becoming a major issue especially due to an array of contradictory opinions either supporting or rejecting institutional care in orphanages (Mwaniki, Mokokha, \& Muttunga, 2015; Raskin, Kotake, Easterbrooks, Ebert, \& Miller, 2015; Zeman \& Zeman, 2005). Western studies strongly criticize the system and status of institutional care in eastern European countries, where

\footnotetext{
* Address for correspondence: Jakub Holický, Department of Pedagogy, Psychology, and Didactics, Faculty of Physical Education and Sport, Charles University, José Martího 31, 16000 Praha 6 - Veleslavín, Czech Republic. E-mail: jakub.holicky@gmail.com
}

different opinions about the system of institutional care result from different historical development (Askeland, 2006; Barth, 2010; Bettmann, Mortensen, \& Akuoko, 2015; Fischer, 2009; Robertson, 2014; Sweeney \& Bascom, 1995; Young \& Richardson, 2007). The most frequent reasons why children receive institutional care is either the economic or social inability of parents, or lack of family care (Dunovský, Dytrych, \& Matějček, 1995; Young \& Richardson, 2007). Even though current statistics confirm a decreasing trend in the number of children placed in various special treatment and protective rehabilitation institutions (Hlado, 2012), the issue of personality development of such children is becoming more relevant (Fischer, 2009; B. S. Miller et al., 2015; Young \& Richardson, 2007). 
There are five basic psychosocial needs (safety, love, belonging, self-esteem and self-actualization) that individuals in childhood need satisfied and whose level of fulfillment or non-fulfillment primarily affects their development in the social, mental and motor domains (Bettmann et al., 2015; Matějček, 2005a). There is an assumption that the development of children receiving institutional care is primarily determined by not addressing these needs (Fischer, 2009; Matějček, 2002; L. C. Miller, 2005; Roeber, Tober, Bolt, \& Pollak, 2012; Young \& Richardson, 2007). An insufficient level of motor proficiency of children is the primary cause of mental and social developmental problems later in life. School-aged children with low levels of motor skills display lower self-confidence, which leads to a more complex socialization process (Bettmann et al., 2015; Fischer, 2009; Robertson, 2014).

Orphanages are one of the care providing institutions and it is especially children from orphanages who are diagnosed with a variety of personality disorders with varying degrees of complexity (Matějček, 2005b; B. S. Miller et al., 2015; Nelson et al., 2007; Roeber et al., 2012). Some studies also critically point to the insufficient space and equipment for children to play, which directly results in insufficient social and motor development (Pollak et al., 2010; Roeber et al., 2012; Tänzler \& Luckner, 2012; Wiik et al., 2011; Young \& Richardson, 2007). Insufficient personality development of children from orphanages in the psychosocial and motor domains may according to some authors later result in retarded development compared to the common developmental norms of a particular society (Goldbeck \& Seitz, 2012; Lin, Cermak, Coster, \& Miller, 2005; Pollak et al., 2010; Roeber et al., 2012; Tirella et al., 2008). Children from orphanages were found to suffer from a higher rate of learning and attention disorders compared to their counterparts from regular families (Dayan \& Cohen, 2011; Leeds, 2007; Willingham, 1998; Wulf, 2007; Wulf, Shea, \& Lewthwaite, 2010). Pomerlau et al. (2005) found that negative effects on development of an individual increase with the length of institutional care. Sweeney and Bascom (1995) and Daunhauer, Bolton, and Cermak (2005) have found that children receiving institutional care spend $50 \%$ of their time on their own, and therefore lack a chance to play with their peers and are exposed to increased risk of social isolation at later age.

There have been some new studies in the Czech Republic (Kokštejn, Psotta, \& Frýbort, 2012; Psotta \& Hendl, 2012; Psotta, Hendl, Frömel, \& Lehnert, 2012) which assessed the level of motor development in school-aged children. However, these studies did not involve children from orphanages. Therefore, it would be appropriate to conduct simultaneous studies dealing with psychomotor development of adolescents placed in orphanages in our country as well. Otherwise, we will tend to accept the results of foreign studies, which however evaluate groups of children who receive institutional care different from that provided in the Czech Republic.

The purpose of the study was to compare the level of psychomotor development of adolescents from orphanages compared to their age-matched counterparts from regular families.

\section{Methods}

\section{Participants}

A total sample of adolescents living in the Prague region $(N=57)$ participated in the study $(13.47 \pm 0.26$ years $)$. The sample of adolescents from regular families ( $n=36$ ) consisted of 23 boys (BMS; $13.36 \pm 0.29$ years) and 13 girls (GMS; $13.61 \pm 0.23$ years). Adolescents in this group were selected from two randomly selected primary schools in Prague according to the official register of the Ministry of Education, Youth and Sports. The sample of adolescents from orphanages $(n=21)$ consisted of 10 boys (BO; $13.52 \pm 0.29$ years) and 11 girls (GO; $13.49 \pm 0.15$ years $)$, which represents a basic sample of adolescents from three orphanages located in Prague. The adolescents from orphanages had spent similar time in orphanages ranging from 3-3.5 years.

All adolescents participating in the study volunteered to take part in the measurements after obtaining written consents from their statutory representatives. The project designed to determine the psychomotor development of adolescents was approved by the Ethics Committee of the Faculty of Physical Education and Sport of Charles University. Adolescents diagnosed with mental or neurological disorders (according to school records) were excluded from the study.

\section{Measurements}

Psychomotor development of adolescents was determined using the long form of test battery BOT-2 (Bruininks-Oseretsky Test of Motor Proficiency - second edition) (Bruininks, 2005). Assessment tool BOT-2 is one of the most widespread and most commonly used test batteries in the field. The test is suitable for individuals aged 4 to 21 (Cools, De Martelaer, Samaey, $\&$ Andries, 2008). The long form of BOT-2 features 52 test items divided into 4 main composites. Each composite consists of two subtests, which represents 12 dimensions overall:

1) Fine manual control
a) Fine motor precision 
b) Fine motor integration

2) Manual coordination

a) Manual dexterity

b) Upper-limb coordination

3) Body coordination

a) Bilateral coordination

b) Balance

4) Strength and agility

a) Running speed and agility

b) Strength

BOT-2 enables the assessment of the level of partial motor competences in both the general population and specific populations, e.g. children with a mental handicap (Fransen et al., 2014; Wang, Long, \& Liu, 2012; Wuang \& Su, 2009). The reliability of BOT-2 is reported to range from 0.90 to 0.97 (Deitz, Kartin, \& Kopp, 2007; Wuang, Lin, \& Su, 2009). Compared to other tests, BOT-2 is frequently used in foreign studies aimed to assess children from orphanages in terms of age range and test reliability (Roeber et al., 2012).

The total test score is calculated using ASSIST software, which forms part of the BOT-2 assessment tool (Bruininks, 2005). ASSIST software converts the Total Point Score (raw score) to Scale Score depending on the age and gender of the participant. Mean and standard deviation for the Scale Score is $15 \pm 5$. The resultant sum of two Scale Scores in a subtest is determined by the Total Test Score, which is converted to the Standard Score according to the gender and age of the participant. Mean and standard deviation of the Standard Score is $50 \pm 10$. Each score is reported with confidence interval of $90 \%$ and $95 \%$. The tables show the percentile rank of the score. In our study the test-retest reliability was very good, with an intraclass correlation coefficient of $I C C=.93(.88-.99)$.

\section{Procedure}

The testing of all adolescents was done in May 2014 according to the BOT-2 manual (Bruininks, 2005). The testing of the children was done by a team of trained research assistants with master's degrees in physical education and sport, special pedagogy or applied physical education. The testing took place in the gymnasiums of particular institutions in the morning hours. The testing facilities met the prescribed criteria according to the BOT-2 manual (Bruininks, 2005), which minimized measurement errors. This was verified within a pilot study, where the conformity of results between examiners was compared. The reliability of conformity was at $\alpha=.93$.

\section{Statistical methods}

Shapiro-Wilk and Kolmogorov-Smirnov tests were used to assess the normality of data distribution $(p \leq .05)$. As the normality of data distribution was not normal, we used nonparametric tests. Practical and statistical significance were used to evaluate differences between groups. To determine practical significance of differences between groups we used eta-squared coefficient $\eta^{2}$ (Cohen, 2013), which was interpreted as follows: $\eta^{2}<.06$ small effect size; $\eta^{2} \geq .13$ moderate effect size; $\eta^{2} \geq .26$ large effect size. Statistical significance of differences between groups was determined using the Mann-Whitney test for 2 independent samples. The data were analyzed using NCSS software (Trial and Past Trial 2005; NCSS, Kaysville, UT, USA), R-cran (Version 3.1.0; package "nparcomp", available from https://cran.r-project.org) and SPSS (Version 22; IBM, Armonk, NY, USA).

\section{Results}

The BOT- 2 assessment tool was used to assess 12 dimensions of psychomotor development in four motor areas: fine manual control, manual coordination, body coordination, and strength and agility. Among the manifest variables are fine motor precision, fine motor integration, manual dexterity, upper-limb coordination, bilateral coordination, balance, strength and running speed and agility. The results of all BOT-2 test dimensions of AO and AMS, BO and BMS and GO and GMS are presented in Table 1, 2 and 3, respectively.

Practical and statistically significant differences between group AO and AMS were determined only in the dimension of fine motor precision $\left(\eta^{2}=.13\right.$; $p=.032$ ) in Table 1. AMS achieved better results in this dimension than adolescents from orphanages. The results in the strength dimension were almost significant $\left(\eta^{2}=.10 ; p=.08\right)$. In this case AO had a higher score. The results for adolescents were comparable between the two groups in the dimensions of fine motor integration, manual dexterity, upper-limb coordination, body coordination and balance. In the dimensions of manual coordination, strength and agility and running speed and agility adolescents from majority society achieved worse results.

A practical and statistically significant difference was determined between boys from majority society and from orphanages only in the dimension of fine motor precision $\left(\eta^{2}=.13 ; p=.028\right)$. In this case boys from majority society achieved higher scores. In the dimension of fine manual control the result was almost significant $\left(\eta^{2}=.10 ; p=.09\right)$. Boys from orphanages 
had higher scores in the dimensions of manual coordination, strength and agility, running speed and agility and strength in comparison to their peers from majority society.

The results of all BOT-2 test dimensions of girls from majority society and girls from orphanages are presented in Table 3. Practical and statistically significant differences between the two groups were not determined in any dimensions. Only in the dimension of strength was there an almost significant difference $\left(\eta^{2}=.09 ; p=.09\right)$. Girls from orphanages achieved higher scores in the dimensions of strength and agility and running speed and agility. Girls from majority society achieved higher scores in the dimension of fine motor precision. In the remaining dimensions, the results between groups were comparable.

\section{Discussion}

The purpose of the present study was to determine and compare the level of psychomotor development of adolescents from orphanages compared to their age-matched counterparts from majority society. The purpose of the study was also to verify the existence of

Table 1

Descriptive statistics of all BOT-2 dimensions for adolescents from majority society and from orphanages

\begin{tabular}{|c|c|c|c|c|c|c|c|c|}
\hline \multirow[b]{2}{*}{ Dimension } & \multicolumn{3}{|c|}{ Majority society } & \multicolumn{3}{|c|}{ Orphanages } & \multirow[b]{2}{*}{$\eta^{2}$} & \multirow[b]{2}{*}{$p$} \\
\hline & Mean $\pm S D$ & Min & Max & Mean $\pm S D$ & Min & Max & & \\
\hline Fine manual control & $42.06 \pm 6.28$ & 32 & 59 & $40.76 \pm 5.64$ & 33 & 52 & .01 & .40 \\
\hline Fine motor precision & $13.83 \pm 4.41$ & 6 & 20 & $11.57 \pm 2.86$ & 7 & 17 & $.13^{\dagger}$ & .03 \\
\hline Fine motor integration & $9.54 \pm 3.02$ & 6 & 18 & $10.19 \pm 3.06$ & 5 & 17 & .01 & .18 \\
\hline Manual coordination & $50.49 \pm 8.08$ & 34 & 63 & $52.05 \pm 9.35$ & 32 & 65 & .02 & .54 \\
\hline Manual dexterity & $17.09 \pm 4.81$ & 7 & 24 & $17.76 \pm 3.62$ & 7 & 22 & .02 & .83 \\
\hline Upper-limb coordination & $13.40 \pm 3.83$ & 7 & 21 & $13.76 \pm 4.97$ & 4 & 21 & .03 & .58 \\
\hline Body coordination & $40.89 \pm 6.77$ & 29 & 53 & $40.52 \pm 6.08$ & 30 & 48 & .01 & .95 \\
\hline Bilateral coordination & $13.94 \pm 4.98$ & 5 & 19 & $13.10 \pm 4.50$ & 6 & 19 & .02 & .70 \\
\hline Balance & $8.71 \pm 2.84$ & 5 & 15 & $8.67 \pm 2.76$ & 6 & 16 & .02 & .95 \\
\hline Strength and agility & $51.11 \pm 7.43$ & 36 & 64 & $52.67 \pm 4.88$ & 44 & 59 & .05 & .33 \\
\hline Running speed and agility & $15.03 \pm 4.69$ & 6 & 26 & $17.38 \pm 6.76$ & 11 & 36 & .02 & .34 \\
\hline Strength & $15.34 \pm 2.92$ & 9 & 21 & $18.48 \pm 6.36$ & 12 & 37 & .10 & .08 \\
\hline
\end{tabular}

Note. Higher scores in dimensions are perceived as better results. ${ }^{\dagger}$ moderate effect size

Table 2

Descriptive statistics of all BOT-2 dimensions for boys from majority society and from orphanages

\begin{tabular}{|c|c|c|c|c|c|c|c|c|}
\hline \multirow[b]{2}{*}{ Dimension } & \multicolumn{3}{|c|}{ Majority society } & \multicolumn{3}{|c|}{ Orphanages } & \multirow[b]{2}{*}{$\eta^{2}$} & \multirow[b]{2}{*}{$p$} \\
\hline & Mean $\pm S D$ & Min & Max & Mean $\pm S D$ & Min & Max & & \\
\hline Fine manual control & $40.86 \pm 6.56$ & 32 & 59 & $37.00 \pm 5.14$ & 33 & 51 & .10 & .09 \\
\hline Fine motor precision & $13.36 \pm 4.79$ & 6 & 20 & $9.40 \pm 2.41$ & 7 & 15 & $.13^{\dagger}$ & .03 \\
\hline Fine motor integration & $8.73 \pm 3.07$ & 6 & 18 & $8.60 \pm 3.37$ & 5 & 17 & .03 & .82 \\
\hline Manual coordination & $48.68 \pm 8.33$ & 34 & 63 & $50.30 \pm 8.06$ & 32 & 59 & .01 & .61 \\
\hline Manual dexterity & $15.77 \pm 4.74$ & 7 & 22 & $16.10 \pm 3.78$ & 7 & 20 & .01 & .82 \\
\hline Upper-limb coordination & $13.36 \pm 4.11$ & 7 & 21 & $14.10 \pm 4.28$ & 7 & 18 & .04 & .48 \\
\hline Body coordination & $39.36 \pm 7.42$ & 29 & 53 & $38.00 \pm 7.53$ & 30 & 48 & .05 & .53 \\
\hline Bilateral coordination & $12.59 \pm 4.98$ & 5 & 18 & $11.60 \pm 5.48$ & 6 & 19 & .05 & .85 \\
\hline Balance & $9.05 \pm 3.12$ & 5 & 15 & $8.00 \pm 2.91$ & 6 & 16 & .04 & .38 \\
\hline Strength and agility & $49.86 \pm 7.50$ & 36 & 64 & $50.80 \pm 1.87$ & 48 & 53 & .03 & .48 \\
\hline Running speed and agility & $14.05 \pm 4.60$ & 6 & 21 & $16.70 \pm 7.09$ & 11 & 36 & .01 & .48 \\
\hline Strength & $15.05 \pm 3.06$ & 9 & 20 & $18.20 \pm 6.65$ & 15 & 37 & .08 & .12 \\
\hline
\end{tabular}

Note. Higher scores in dimensions are perceived as better results. "moderate effect size 
Table 3

Descriptive statistics of the results of BOT-2 dimensions for girls from majority society and from orphanages

\begin{tabular}{|c|c|c|c|c|c|c|c|c|}
\hline \multirow[b]{2}{*}{ Dimension } & \multicolumn{3}{|c|}{ Majority society } & \multicolumn{3}{|c|}{ Orphanages } & \multirow[b]{2}{*}{$\eta^{2}$} & \multirow[b]{2}{*}{$p$} \\
\hline & Mean $\pm S D$ & Min & $\operatorname{Max}$ & Mean $\pm S D$ & Min & $\operatorname{Max}$ & & \\
\hline Fine manual control & $44.08 \pm 5.42$ & 37 & 50 & $44.18 \pm 3.57$ & 39 & 52 & .01 & .95 \\
\hline Fine motor precision & $14.62 \pm 3.73$ & 8 & 20 & $13.55 \pm 1.44$ & 12 & 17 & .01 & .53 \\
\hline Fine motor integration & $10.92 \pm 2.47$ & 8 & 16 & $11.64 \pm 1.91$ & 10 & 16 & .02 & .27 \\
\hline Manual coordination & $53.54 \pm 6.88$ & 37 & 63 & $53.64 \pm 10.51$ & 39 & 65 & .02 & .69 \\
\hline Manual dexterity & $19.31 \pm 4.21$ & 10 & 24 & $19.27 \pm 2.83$ & 14 & 22 & .01 & .82 \\
\hline Upper-limb coordination & $13.46 \pm 3.45$ & 9 & 21 & $13.45 \pm 5.72$ & 4 & 21 & .02 & .91 \\
\hline Body coordination & $43.46 \pm 4.70$ & 36 & 52 & $42.82 \pm 3.28$ & 38 & 46 & .02 & .95 \\
\hline Bilateral coordination & $16.23 \pm 4.23$ & 9 & 19 & $14.45 \pm 3.05$ & 12 & 19 & .03 & .39 \\
\hline Balance & $8.15 \pm 2.30$ & 6 & 13 & $9.27 \pm 2.61$ & 7 & 13 & .04 & .27 \\
\hline Strength and agility & $53.23 \pm 7.10$ & 40 & 64 & $54.36 \pm 6.15$ & 44 & 59 & .02 & .53 \\
\hline Running speed and agility & $16.69 \pm 4.52$ & 10 & 26 & $18.00 \pm 6.72$ & 12 & 36 & .01 & .95 \\
\hline Strength & $15.85 \pm 2.70$ & 10 & 21 & $18.73 \pm 6.40$ & 12 & 36 & .09 & .09 \\
\hline
\end{tabular}

Note. Higher scores in dimensions are perceived as better results.

differences in psychomotor development in relation to the gender of study participants.

According to international studies adolescents from orphanages have significantly lower levels in multiple dimensions of psychomotor skills (Pollak et al., 2010; Roeber et al., 2012). One study showed that $34 \%$ of adolescents and children from institutionalized care, who had spent 5 years or more in orphanages, had an impaired level of fine and gross motor skills and balance (Pollak et al., 2010). As reported by other researchers (Pollak et al., 2010; Roeber, Gunnar, \& Pollak, 2014, Mehta et al., 2009; Roeber et al., 2012; Wiik et al., 2011), further consequences of such changes could manifest in other areas of children's psychomotor development, not only in the dimensions of balance and bilateral coordination. Children and adolescents from orphanages had significantly lower scores in the area of balance and bilateral coordination in comparison to their peers raised in their birth families (Roeber et al., 2014; Roeber et al., 2012). One of the reasons is the environment of orphanages which cannot sufficiently stimulate optimal development of an individual (Gunnar, 2001). The results of our study have shown that adolescents from orphanages achieved significantly lower scores only in the area of fine motor precision $\left(\eta^{2}=.13 ; p=.032\right)$. In the remaining motor areas, there were no significant differences between adolescents from orphanages and their counterparts from majority society. In the dimensions of balance $\left(\eta^{2}=.02 ; p=.95\right)$ and bilateral coordination $\left(\eta^{2}=.02\right.$; $p=.70)$ a significant difference between groups was not identified. But it is important to mention that adolescents from grade school did achieve slightly higher scores than adolescents from orphanages in the dimensions of bilateral coordination and balance.

Foreign studies point to the fact that in the area of behavioral plasticity boys and girls from orphanages lack primary experience, which children obtain through competitions and games with their peers (Mehta et al., 2009; Wilbarger, Gunnar, Schneider, \& Pollak, 2010). Neurological studies on children following institutional deprivation have reported negative structural and functional changes in brain areas including cerebellum (Bauer, Hanson, Pierson, Davidson, \& Pollak, 2009; Mehta et al., 2009). Pollak et al. (2010) found that boys and girls from orphanages had a significant level of gross motor skills. Therefore we had expected to find that boys from orphanages would have significantly lower scores in the tests for balance and bilateral coordination. But our study showed practical and significant differences only in the dimension of fine motor precision $\left(\eta^{2}=.13 ; p=.028\right)$. Our study did not find a significant difference in the area of bilateral coordination or balance as the international study by Pollak et al. (2010) did. It is very important to mention that in the dimension of bilateral coordination, balance and body coordination boys from majority society achieved higher scores than boys from orphanages. Boys from orphanages achieved worse results in 6 of the 12 dimensions than boys from majority society. These results are comparable to the results of the whole sample.

Our analysis did not identify any significant difference between groups of girls from orphanages and majority society. Girls from orphanages were better in 7 of the 12 dimensions than girls from majority society. 
Almost significant difference was found in the dimension of strength. In this dimension, girls from majority society achieved worse scores than girls from orphanages. We found that adolescents from orphanages, boys and girls, achieved higher scores in the dimensions of strength and agility, running speed and agility and strength.

Although studies conducted in the Czech Republic and foreign studies over the past 20 years emphasize defects in institutional care settings, which result in insufficient development of individuals, the present study has not confirmed the findings of these studies. The results of our study may be attributed to sociocultural differences in the society where the study was conducted. The system of institutionalizing children in the Czech Republic is different from that in other European countries (Matějček, 2002). Over the past 20 years, there have been significant differences in the management of orphanages. Employees and educational counselors in orphanages have to meet strict qualification criteria in order to become part of the educational personnel in orphanages. At the same time, thanks to partial state financial support, to a certain extent orphanages can use facilities such as gymnasiums and playgrounds for children to engage in physical activity and can also buy a certain number of toys and games, which children play with in their free time. These facts may play a crucial role in children acquiring a sufficient range of basic motor skills and attaining physical activity levels.

The research itself and data interpretation have to be confined within certain limits. The results of this study cannot be generalized to the entire Czech population. The research included adolescents living in the area of the capital city of Prague with all orphanages participating in the research. With regard to the age of adolescents living in orphanages, we focused on the age group of 13 year olds. Due to the extent of the study, we believe it would be appropriate to do further research and study other relevant variables which could have had significant effect on the results of the study, such as physical activity levels of adolescents. Physical activity is one of the strongest determinants of motor development. Therefore it is important to involve physical activity in future studies.

\section{Conclusion}

Our study found significantly worse scores by adolescents from orphanages only in the dimension of fine motor precision. This result was confirmed by boys from orphanages who achieved significantly worse scores in this dimension in comparison to boys from majority society too. On the other hand, we did not find any significant difference between girls from orphanages and majority society. According to the results of our study, institutional care is not a factor underlying delayed psychomotor development of pubertal adolescents. However, other research has claimed that institutional care has a negative impact on psychomotor development by boys and girls. Due to the fact that this study was conducted only on 13 year old adolescents, we recommend studying the entire pubertal age range between 11 and 16 years and prepubertal age as well. A longitudinal study designed to study adolescents would be most appropriate in terms of examining psychomotor development of boys and girls receiving institutional care.

\section{Acknowledgments}

This study was conducted and supported by project SVV FTVS 260236, project GAUK No. 474214, project No. GP14-29358P and within program PRVOUK No. 39 "The examination of the human body from the viewpoint of social sciences".

\section{References}

Askeland, L. (2006). Children and youth in adoption, orphanages, and foster care: A historical handbook and guide. Santa Barbara, CA: Greenwood Press.

Barth, D. (2010). Kinderheim Baumgarten [Orphanage tree of garden]. Düsseldorf, Germany: BoD - Books on Demand.

Bauer, P. M., Hanson, J. L., Pierson, R. K., Davidson, R. J., \& Pollak, S. D. (2009). Cerebellar volume and cognitive functioning in children who experienced early deprivation. Biological Psychiatry, 66, 1100-1106.

Bettmann, J. E., Mortensen, J. M., \& Akuoko, K. O. (2015). Orphanage caregivers' perceptions of children's emotional needs. Children and Youth Services Review, 49, 71-79.

Bruininks, R. H. (2005). Bruininks-Oseretsky Test of Motor Proficiency (BOT-2). Minneapolis, MN: Pearson Assessment.

Cohen, J. (2013). Statistical power analysis for the behavioral sciences (2nd rev. ed.). New York, NY: Taylor \& Francis.

Cools, W., De Martelaer, K., Samaey, C., \& Andries, C. (2008). Movement skill assessment of typically developing preschool children: A review of seven movement skill assessment tools. Journal of Sports Science and Medicine, 8, 154-168.

Daunhauer, L. A., Bolton, A., \& Cermak, S. A. (2005). Timeuse patterns of young children institutionalized in Eastern Europe. OTJR: Occupation, Participation and Health, 25, 33-40.

Dayan, E., \& Cohen, L. G. (2011). Neuroplasticity subserving motor skill learning. Neuron, 72, 443-454. 
Deitz, J. C., Kartin, D., \& Kopp, K. (2007). Review of the Bruininks-Oseretsky Test of Motor Proficiency (BOT-2). Physical \& Occupational Therapy in Pediatrics, 27, 87-102.

Dunovský, J., Dytrych, Z., \& Matějček, Z. (1995). Týrané, zneuživané a zanedbávané ditě [Abused and neglected child]. Prague, Czech Republic: Grada.

Fischer, S. (2009). Sociální patologie [Social pathology]. Prague, Czech Republic: Grada.

Fransen, J., D’Hondt, E., Bourgois, J., Vaeyens, R., Philippaerts, R. M., \& Lenoir, M. (2014). Motor competence assessment in children: Convergent and discriminant validity between the BOT- 2 short form and KTK testing batteries. Research in Developmental Disabilities, 35, 1375-1383.

Goldbeck, L., \& Seitz, D. C. (2012). Das Traumanarrativ in der Kinderpsychotherapie [The trauma in child psychotherapy]. Zeitschrift für Individualpsychologie, 37, 345-355.

Gunnar, M. R. (2001). Effects of early deprivation: Findings from orphanage-reared infants and children. In C. A. Nelson \& M. Luciana (Eds.), Handbook of developmental cognitive neuroscience (pp. 617-629). Cambridge, MA: MIT Press.

Hlad'o, P. (2012). Profesní orientace adolescentů: pohledy $z$ teorií a výzkumů [Professional affiliations of adolescents: Views from theory and research]. Bratislava, Slovakia: Konvoj.

Kokštejn, J., Psotta, R., \& Frýbort, P. (2012). Relationships between levels of motor coordination, attention and physical activity in children: The mediation model. Acta Universitatis Palackianae Olomucensis. Gymnica, 42(4), 29-40.

Leeds, J. (2007). Attention and motor skill learning. International Journal of Sports Science and Coaching, 2, 329-334.

Lin, S. H., Cermak, S., Coster, W. J., \& Miller, L. (2005). The relation between length of institutionalization and sensory integration in children adopted from Eastern Europe. American Journal of Occupational Therapy, 59, 139-147.

Matějček, Z. (2002). Osvojení a pěstounská péce [Adoption and foster care]. Prague, Czech Republic: Portál.

Matějček, Z. (2005a). Prvních 6 let ve vývoji a výchově dítěte [The first 6 years in development and upbringing of the child]. Prague, Czech Republic: Grada.

Matějček, Z. (2005b). Výbor z díla [Anthology of the work]. Prague, Czech Republic: Karolinum.

Mehta, M. A., Golembo, N. I., Nosarti, C., Colvert, E., Mota, A., Williams, S. C., \& Sonuga-Barke, E. J. (2009). Amygdala, hippocampal and corpus callosum size following severe early institutional deprivation: The English and Romanian Adoptees Study Pilot. Journal of Child Psychology and Psychiatry, 50, 943-951.

Miller, B. S., Spratt, E. G., Himes, J. H., Condon, D., Summer, A., Papa, C. E., \& Brady, K. T. (2015). Growth failure associated with early neglect: Pilot comparison of neglected US children and international adoptees. Journal of Pediatric Endocrinology and Metabolism, 28, 111-115.

Miller, L. C. (2005). International adoption, behavior, and mental health. JAMA, 293, 2533-2535.

Mwaniki, E., Mokokha, A., \& Muttunga, J. (2015). Nutrition status and associated morbidity risk factors among orphanage and non-orphanage children in selected public primary schools within Dagoretti, Nairobi, Kenya. East African Medical Journal, 91, 289-297.
Nelson, C. A., Zeanah, C. H., Fox, N. A., Marshall, P. J., Smyke, A. T., \& Guthrie, D. (2007). Cognitive recovery in socially deprived young children: The Bucharest Early Intervention Project. Science, 318, 1937-1940.

Pollak, S. D., Nelson, C. A., Schlaak, M. F., Roeber, B. J., Loman, M. M., \& Gunnar, M. R. (2010). Neurodevelopmental effects of early deprivation in postinstitutionalized children. Child Development, 81, 224-236.

Pomerleau, A., Malcuit, G., Chicoine, J. F., Séguin, R., Belhumeur, C., Germain, P., ... Jéliu, G. (2005). Health status, cognitive and motor development of young children adopted from China, East Asia, and Russia across the first 6 months after adoption. International Journal of Behavioral Development, 29, 445-457.

Psotta, R., \& Hendl, J. (2012). Movement Assessment Battery for Children - second edition: Cross-cultural comparison between 11-15 year old children from the Czech Republic and the United Kingdom. Acta Universitatis Palackianae Olomucensis. Gymnica, 42(3), 7-16.

Psotta, R., Hendl, J., Frömel, K., \& Lehnert, M. (2012). The second version of the Movement Assessment Battery for Children: A comparative study in 7-10 year old children from the Czech Republic and the United Kingdom. Acta Universitatis Palackianae Olomucensis. Gymnica, 42(4), 19-27.

Raskin, M., Kotake, C., Easterbrooks, M. A., Ebert, M., \& Miller, L. C. (2015). Job-related stress and depression in orphanage and preschool caregivers in Ukraine. Journal of Research in Childhood Education, 29, 130-145.

Robertson, K. (2014). The importance of sisters: Indian girls reflect on their experience in an orphanage. Institutionalised Children Explorations and Beyond, 1, 163-172.

Roeber, B. J., Gunnar, M. R., \& Pollak, S. D. (2014). Early deprivation impairs the development of balance and bilateral coordination. Developmental Psychobiology, 56, 1110-1118.

Roeber, B. J., Tober, C. L., Bolt, D. M., \& Pollak, S. D. (2012). Gross motor development in children adopted from orphanage settings. Developmental Medicine \& Child Neurology, 54, 527-531.

Sweeney, J. K., \& Bascom, B. B. (1995). Motor development and self-stimulatory movement in institutionalized Romanian children. Pediatric Physical Therapy, 7, 124-132.

Tänzler, B., \& Luckner, S. (2012). Kinderheim statt Kinderzimmer: neun Leben danach [Orphanage takes children: Nine lives after]. Zürich, Switzerland: Urs Bernet.

Tirella, L., Chan, W., Cermak, S., Litvinova, A., Salas, K., \& Miller, L. (2008). Time use in Russian baby homes. Child: Care, Health and Development, 34, 77-86.

Wang, H. Y., Long, I. M., \& Liu, M. F. (2012). Relationships between task-oriented postural control and motor ability in children and adolescents with Down syndrome. Research in Developmental Disabilities, 33, 1792-1798.

Wiik, K. L., Loman, M. M., Van Ryzin, M. J., Armstrong, J. M., Essex, M. J., Pollak, S. D., \& Gunnar, M. R. (2011). Behavioral and emotional symptoms of post-institutionalized children in middle childhood. Journal of Child Psychology and Psychiatry, 52, 56-63.

Wilbarger, J., Gunnar, M., Schneider, M., \& Pollak, S. (2010). Sensory processing in internationally adopted, 
post-institutionalized children. Journal of Child Psychology and Psychiatry, 51, 1105-1114.

Willingham, D. B. (1998). A neuropsychological theory of motor skill learning. Psychological Review, 105, 558-584.

Wuang, Y. P., Lin, Y. H., \& Su, C. Y. (2009). Rasch analysis of the Bruininks-Oseretsky Test of Motor Proficiency - second edition in intellectual disabilities. Research in Developmental Disabilities, 30, 1132-1144.

Wuang, Y. P., \& Su, C. Y. (2009). Reliability and responsiveness of the Bruininks-Oseretsky Test of Motor Proficiency - second edition in children with intellectual disability. Research in Developmental Disabilities, 30, 847-855.
Wulf, G. (2007). Attention and motor skill learning. Champaign, IL: Human Kinetics.

Wulf, G., Shea, C., \& Lewthwaite, R. (2010). Motor skill learning and performance: A review of influential factors. Medical Education, 44, 75-84.

Young, M. E., \& Richardson, L. M. (2007). Early child development, from measurement to action: A priority for growth and equity. Washington, DC: World Bank.

Zeman, J., \& Zeman, L. (2006). Z dějin pěstounské péče v Českých zemích [From the history of foster care]. Časopis lékařu českých, 145, 673-674. 